This article was downloaded by: [National Taiwan University]

On: 16 December 2008

Access details: Access Details: [subscription number 788846425]

Publisher Taylor \& Francis

Informa Ltd Registered in England and Wales Registered Number: 1072954 Registered office: Mortimer House, 37-41 Mortimer Street, London W1T 3JH, UK

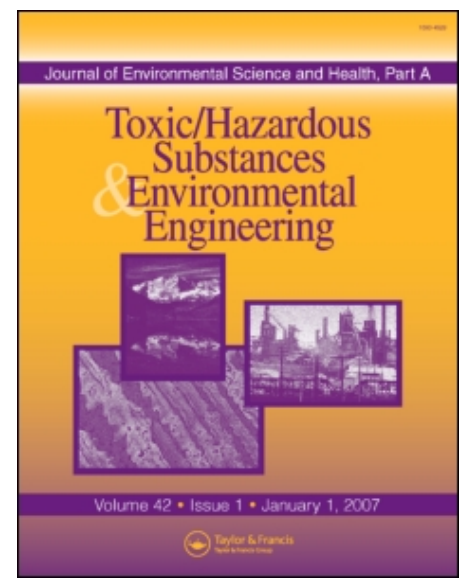

Journal of Environmental Science and Health, Part A

Publication details, including instructions for authors and subscription information: http://www.informaworld.com/smpp/title content=t713597268

\title{
Regeneration and Reuse of Water Treatment Plant Sludge: Adsorbent for Cations \\ Chung-Hsin Wu ${ }^{\mathrm{a}}$; Cheng-Fang Lin ${ }^{\mathrm{b}}$; Wan-Ru Chen ${ }^{\mathrm{b}}$
}

a Department of Environmental Engineering and Health, Yuanpei University of Science and Technology,

Hsinchu, Taiwan, $\mathrm{ROC}^{\mathrm{b}}$ Graduate Institute of Environmental Engineering, National Taiwan University, Taipei,

Taiwan, ROC

Online Publication Date: 01 January 2005

To cite this Article Wu, Chung-Hsin, Lin, Cheng-Fang and Chen, Wan-Ru(2005)'Regeneration and Reuse of Water Treatment Plant Sludge: Adsorbent for Cations',Journal of Environmental Science and Health, Part A,39:3,717 - 728

To link to this Article: DOI: 10.1081/ESE-120027737

URL: http://dx.doi.org/10.1081/ESE-120027737

\section{PLEASE SCROLL DOWN FOR ARTICLE}

\footnotetext{
Full terms and conditions of use: http://www.informaworld.com/terms-and-conditions-of-access.pdf

This article may be used for research, teaching and private study purposes. Any substantial or systematic reproduction, re-distribution, re-selling, loan or sub-licensing, systematic supply or distribution in any form to anyone is expressly forbidden.

The publisher does not give any warranty express or implied or make any representation that the contents will be complete or accurate or up to date. The accuracy of any instructions, formulae and drug doses should be independently verified with primary sources. The publisher shall not be liable for any loss, actions, claims, proceedings, demand or costs or damages whatsoever or howsoever caused arising directly or indirectly in connection with or arising out of the use of this material.
} 
JOURNAL OF ENVIRONMENTAL SCIENCE AND HEALTH

Part A-Toxic/Hazardous Substances \& Environmental Engineering

Vol. A39, No. 3, pp. 717-728, 2004

\title{
Regeneration and Reuse of Water Treatment Plant Sludge: Adsorbent for Cations
}

\author{
Chung-Hsin Wu, ${ }^{1, *}$ Cheng-Fang Lin, ${ }^{2}$ and Wan-Ru Chen ${ }^{2}$ \\ ${ }^{1}$ Department of Environmental Engineering and Health, Yuanpei University of \\ Science and Technology, Hsinchu, Taiwan, ROC \\ ${ }^{2}$ Graduate Institute of Environmental Engineering, \\ National Taiwan University, Taipei, Taiwan, ROC
}

\begin{abstract}
This study applies sintering technology to convert water sludge to a useful and stable adsorption material. The properties of the sintered materials were characterized using SEM and BET. Additionally, adsorption experiments were conducted to elucidate interactions of $\mathrm{Cr}$ (III) and $\mathrm{Hg}$ (II) at the interface between water and sintered material. Elemental analysis of original water sludge indicates its main constituents to be $\mathrm{SiO}_{2}(54 \%), \mathrm{Al}_{2} \mathrm{O}_{3}(21 \%)$, and $\mathrm{Fe}_{2} \mathrm{O}_{3}(6.6 \%)$. The BET measurement indicated that the specific surface area of the sintered material is $4.6 \mathrm{~m}^{2} / \mathrm{g}$. Since the $\mathrm{SiO}_{2}$ content exceeds $50 \%$, the surface of the sintered material becomes negatively charged. Adsorption of $\mathrm{Cr}(\mathrm{III})$ and $\mathrm{Hg}(\mathrm{II})$ on sintered material shows that sorption depends on the systems' $\mathrm{pH}$. The sorption densities are $1.40 \mathrm{mg} \mathrm{Cr} / \mathrm{g}$ at equilibrium $\mathrm{pH} 4.6$ and $0.43 \mathrm{mg} \mathrm{Hg} / \mathrm{g}$ at equilibrium $\mathrm{pH} 6.0$. Background electrolyte does not affect the sorption of $\mathrm{Cr}$ (III) but markedly affects the sorption of $\mathrm{Hg}(\mathrm{II})$. The affinity of $\mathrm{Cr}(\mathrm{III})$ for surface reacting sites seem to exceed that of $\mathrm{Hg}(\mathrm{II})$. Competitive adsorption experiments were performed to determine the magnitude of the variations in adsorption due to
\end{abstract}

*Correspondence: Chung-Hsin Wu, Department of Environmental Engineering and Health, Yuanpei University of Science and Technology, 306 Yuanpei St., Hsinchu 300, Taiwan, ROC; Fax: 886-3-5385353; E-mail: chwu@mail.yust.edu.tw. 
competitive interactions among $\mathrm{Cr}$ (III) and $\mathrm{Hg}(\mathrm{II})$. The experimental results indicate that a higher competitive solute concentration results in a more significant competitive effect on $\mathrm{Hg}(\mathrm{II})$.

Key Words: $\mathrm{Cr}(\mathrm{III})$; $\mathrm{Hg}(\mathrm{II})$; Water treatment plant sludge; Sinter; Adsorption.

\section{INTRODUCTION}

Water treatment plant sludge left after water clarification contains the impurities filtered out of the water and the chemicals added for clarification. More than $2.4 \times 10^{7}$ tons $(70 \%$ wt.) water treatment plant sludge is generated each year in Taiwan. Due to the shortage of landfill sites, disposal of waste has gained much concern in Taiwan in recent years. Although the heavy metals leaching potency of the water treatment plant sludge could meet the toxicity characteristic leaching procedure (TCLP) standard usually, its disposal directly to landfill in Taiwan could not meet the trend of resource recovery policy.

Recycling the water treatment plant sludge is usually an attempt to reduce its volume, make it harmless and stable, recover useful contents and facilitate its safe disposal without imposing burden to environment. Transforming waste into useful materials requires that its chemical characteristics be investigated and the cost of its reuse be reduced to increase resultant products' competitiveness in the marketplace. The water treatment plant sludge left after water clarification contains mainly inorganic and stable substances, such as $\mathrm{Si}, \mathrm{Ca}, \mathrm{Fe}$, and $\mathrm{Al}$, and much colloidal earth materials. The problem of disposal can be solved, the life of waste disposal facilities increased, and the demand for natural resources reduced by transforming the water treatment plant sludge into reusable substance.

The purity of the coagulants recovered from clarifier sludge may not be sufficient to justify their reuse in potable water operations. ${ }^{[1]}$ Therefore, a new ion exchange process was further explored for selective removal, separation, and recovery of $\mathrm{Fe}(\mathrm{III})$ and $\mathrm{Al}(\mathrm{III})$ species from the clarifier sludge. ${ }^{[2]}$ Trance metals present in the clarifier sludge are recovered and safely disposed in landfill. Sewage sludge was a valuable resource and that could be reused as soil conditioner. ${ }^{[3]}$ Sewage sludge also could be stabilized by pulverized fuel ash and the product was recycled into a material for land reclamation, as a soil conditioner and as cover material for landfill. ${ }^{[4]}$ The wastewater sludge reuse ways in South Australia included using in woodlots, brick-making, landscaping, and mine site rehabilitation. ${ }^{[5]}$ Liaw et al. ${ }^{[6]}$ employed granulation and sintering techniques to make the paper sludge into constructional bricks. Bricks containing 10\% tannery sludge can be used safely and the properties of ceramic materials are acceptable. ${ }^{[7]}$ Wastewater sludge and sludge ash can be used in the production of bricks or can be as a replacement to the bricks production. ${ }^{[8-12]}$ Bricks made of $50 \%$ wt. harbour sediments at a temperature of $1050^{\circ} \mathrm{C}$ thermal treatment lead to an immobilization of most trace contaminants. ${ }^{[13]}$ Alum sludge can be reused to remove heavy metal in wastewater and reduce the fresh alum dosage. ${ }^{[14]}$ Different techniques have been applied to reuse sludge and also to solve the problem of insufficient landfill sites. However, there is no work to reuse 
sludge as adsorbent. Therefore, this study employs the sintering process to treat sludge and reuse it in wastewater treatment.

Adsorbents are increasingly substituted by natural by-products or stabilized solid materials to develop cost-effective composite adsorbents that can treat various contaminants. Water treatment plant sludge contains only few organic substances but much colloid, and is thus very suitable for sintering. According to Nowok et al., ${ }^{[15]}$ the high pressure and temperature during sintering alter the crystalline phase of the sludge, and the colloids to metal oxides. Sintering the water treatment plant sludge is a process of stabilization that reduces the probability that the water treatment plant sludge releases harmful substances when it is recycled. This work employs the sinter produced by sintering water treatment plant sludge at high temperature as an adsorbent, to elucidate the adsorption of cations on the surface of the sinter. The experiments include adsorption of $\mathrm{Cr}(\mathrm{III})$ and $\mathrm{Hg}$ (II) by water treatment plant sludge and sintered material. Furthermore, the competitive adsorption of $\mathrm{Cr}(\mathrm{III})$ and $\mathrm{Hg}(\mathrm{II})$ and the adsorption density of cation on the sintered material was also investigated. This study provides some insight into the interactions among $\mathrm{Cr}(\mathrm{III}), \mathrm{Hg}(\mathrm{II})$, and sintered material. The objective of this study is to transform the water treatment plant sludge into a resource and reuse it for treating wastewater containing toxic ions.

\section{MATERIALS AND METHODS}

\section{Preparation and Purification of Adsorbent}

The water treatment plant sludge used in this research was obtained from Taipei Chih-Tan Water Treatment Plant. The composition of the water treatment plant sludge is analyzed using inductively coupled plasma atomic emission spectroscopy (ICP-AES). The sludge was smashed and ground first. Then the ground water treatment plant sludge was placed in an oven and dried to a constant mass. Approximately $5 \mathrm{wt} \%$ water was used as a binder in the ground sludge powder, which was mixed evenly. Then $10.9 \mathrm{MPa}$ of forming pressure was applied and the sludge was heated at $1000^{\circ} \mathrm{C}$ for $1.5 \mathrm{~h}$.

The sintered material is ground and sieved through a \#200 sieve to obtain the adsorbent used in this study. The excess salts on the surface must be removed with deionized water since various function groups on the surface of the sinter might affect its capacity to adsorb. Accordingly, the filtered sinter is mixed with deionized water (D. I. Water, Milli-Q) and, after the mixture, the subsided sludge is washed to remove the excess salts by reverse osmosis. It is then soaked with a large quantity of deionized water. The deionized water is occasionally renewed during the process. The washing is complete when the electrical conductivity of the water for washing the sintered powder equals that of the deionized water. The washed sinter is removed from the reverse osmosis. It is placed in an oven and dried at $103^{\circ} \mathrm{C}$. The adsorbent used in this study is thus prepared.

The specific surface areas of the water treatment plant sludge and the sintered material, determined by the $\mathrm{N}_{2}$ Brunauer-Emmett-Teller sorption experiments, are 30.5 and $4.6 \mathrm{~m}^{2} / \mathrm{g}$, respectively. 


\section{Adsorption Experiments}

The chemicals used in this research are all reagent grade. The $1 \mathrm{mM} \mathrm{Cr}$ (III) stock solution is prepared with $\mathrm{CrCl}_{3}$; the $0.2 \mathrm{mM} \mathrm{Hg}(\mathrm{II})$ stock solution is prepared with $\mathrm{HgCl}_{2}$. The $1 \mathrm{~N}$ background electrolyte resolution is prepared with $\mathrm{NaCl}$.

The experiment on the equilibrium adsorption of cations is conducted in a $100 \mathrm{~mL}$ plastic bottle. The concentration of the adsorbent during the test is $5 \mathrm{~g} / \mathrm{L}$, while the concentration of $\mathrm{Cr}(\mathrm{III})$ and $\mathrm{Hg}$ (II) is 40 and $2 \mu \mathrm{M}$, respectively. The $\mathrm{pH}$ values are controlled using $1 \mathrm{~N} \mathrm{NaOH}$ and $1 \mathrm{~N} \mathrm{HCl}$. The concentration of the background electrolyte is controlled with $\mathrm{NaCl}$ at $0.1 \mathrm{~N}, 0.01 \mathrm{~N}$, and $0.001 \mathrm{~N}$. Solution containing cations and adsorbent are then equilibrated for $20 \mathrm{~h}$ at $25^{\circ} \mathrm{C}$ and shaked at $200 \mathrm{rpm}$. In the competitive adsorption experiments, $\mathrm{Hg}(\mathrm{II})(2 \mu \mathrm{M})$ was equilibrated with the sintered material $(5 \mathrm{~g} / \mathrm{L})$, and the concentrations of competitive solutes $(\mathrm{Cr}(\mathrm{III}))$ were between 40 and $400 \mu \mathrm{M}$. A little $\mathrm{HCl}$ or $\mathrm{NaOH}$ was added to cover the $\mathrm{pH}$ range from 2 to 8 for the reactions. The $\mathrm{pH}$ values of all the samples that reach equilibrium are measured and the samples are then put into a centrifuge for $10 \mathrm{~min}$ at $3000 \mathrm{rpm}$. A $0.2 \mu \mathrm{m}$ filter membrane (Gelman Sciences) is then used to filter the supernatant. The concentration of $\mathrm{Cr}(\mathrm{III})$ and $\mathrm{Hg}(\mathrm{II})$ is measured using AA (Atomic Adsorption, Perkin Elmer 5000).

\section{RESULTS AND DISCUSSION}

\section{Composition of the Water Treatment Plant Sludge}

The composition of the water treatment plant sludge is shown in Table 1. The water treatment plant sludge contains mainly $\mathrm{SiO}_{2}$, representing approximately $54 \%$ of the total content of the water treatment plant sludge. The other substances in the water treatment plant sludge are $\mathrm{Al}_{2} \mathrm{O}_{3}$ and $\mathrm{Fe}_{2} \mathrm{O}_{3}$, in percentage order.

Table 1. Characterization of the water treatment plant sludge.

\begin{tabular}{lc}
\hline Component & $\begin{array}{r}\text { Percentage } \\
\text { (wt. \%) }\end{array}$ \\
\hline $\mathrm{SiO}_{2}$ & 53.6 \\
$\mathrm{Al}_{2} \mathrm{O}_{3}$ & 20.9 \\
$\mathrm{Fe}_{2} \mathrm{O}_{3}$ & 6.6 \\
$\mathrm{MgO}$ & 1.9 \\
$\mathrm{CaO}$ & 0.3 \\
$\mathrm{PbO}$ & 0.2 \\
$\mathrm{CuO}$ & $<0.1$ \\
$\mathrm{ZnO}$ & $<0.1$ \\
$\mathrm{Cr}$ & $<\mathrm{O}_{3}$ \\
$\mathrm{CdO}$ & $<0.1$ \\
\hline
\end{tabular}


The specific surface area of the sintered material $\left(4.6 \mathrm{~m}^{2} / \mathrm{g}\right)$ is smaller than the water treatment plant sludge $\left(30.5 \mathrm{~m}^{2} / \mathrm{g}\right)$, because the gaps between the particles are filled by the particles' neck growth between them that makes the sinter finer. This work aims to make the gaps between such particles finer and, consequently, prevent the dissolution of a harmful substance during the adsorption process.

\section{Adsorption Envelope of $\mathrm{Cr}(\mathrm{III})$ and $\mathrm{Hg}$ (II) onto Water Treatment Plant Sludge}

Figure 1 presents the adsorption envelope of $\mathrm{Cr}(\mathrm{III})$. The adsorption percentage increases with $\mathrm{pH}$, because the number of active sites of positive charge on the surface of the oxide is higher at a lower $\mathrm{pH}$, reducing the tendency of cations to adsorb onto the surface.

Figure 1 depicts the adsorption envelope of $\mathrm{Hg}(\mathrm{II})$. The adsorption percentage exceeds $90 \%$ when equilibrium $\mathrm{pH}<6.5$. Unlike that of the cations, the adsorption percentage of $\mathrm{Hg}(\mathrm{II})$ does not increase, but declines slightly as $\mathrm{pH}$ increases. Adhesion between $\mathrm{Hg}(\mathrm{II})$ and the organic substance in the water treatment plant sludge may exceed that caused by the electrical attraction between $\mathrm{Hg}$ (II) and the surface of the water treatment plant sludge. Therefore, the adsorption percentage does not decline due to fewer negatively charged sites on the surface of the oxide when the $\mathrm{pH}$ is low.

The adsorption density of $\mathrm{Cr}(\mathrm{III})$ and $\mathrm{Hg}(\mathrm{II})$ onto water treatment plant sludge at equilibrium $\mathrm{pH}=5$ is $2.62 \times 10^{-4} \mathrm{mmol} / \mathrm{m}^{2}$ and $1.31 \times 10^{-5} \mathrm{mmol} / \mathrm{m}^{2}$. This result shows that the affinity of $\mathrm{Cr}$ (III) on the surface of sludge is higher than $\mathrm{Hg}$ (II).

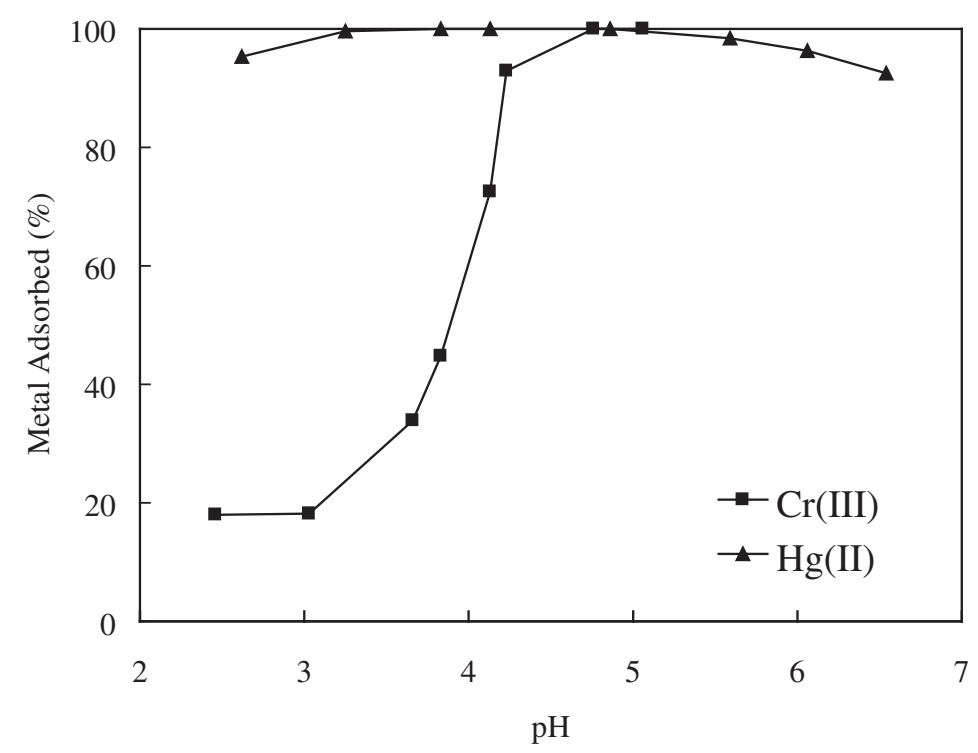

Figure 1. Adsorption of $\mathrm{Cr}(\mathrm{III})$ and $\mathrm{Hg}(\mathrm{II})$ by water treatment plant sludge as a function of $\mathrm{pH}\left([\mathrm{Cr}(\mathrm{III})]_{\mathrm{T}}=40 \mu \mathrm{M},[\mathrm{Hg}(\mathrm{II})]_{\mathrm{T}}=2 \mu \mathrm{M}\right.$, adsorbent $=5 \mathrm{~g} / \mathrm{L}$, and $\left.25^{\circ} \mathrm{C}\right)$. 


\section{Adsorption of $\mathrm{Cr}(\mathrm{III})$ and $\mathrm{Hg}(\mathrm{II})$ onto the Sintered Material}

The adsorption percentage of $\mathrm{Cr}$ (III) increases with the $\mathrm{pH}$ (Fig. 2a), revealing that the number of deprotonated sites on the surface of the sinter increases with the $\mathrm{pH}$, facilitating the adsorption of the cations. As Fig. 2a shows, the background electrolyte $(\mathrm{NaCl})$ does not clearly affect the adsorption of $\mathrm{Cr}(\mathrm{III})$, perhaps because the o-plane complex reaction of $\mathrm{Cr}$ (III) is not influenced by the $\beta$-plane complex reaction of the background electrolyte $\left(\mathrm{Na}^{+}\right.$and $\left.\mathrm{Cl}^{-}\right)$. Csoban and $\mathrm{Joo}^{[16]}$ stated that $\mathrm{Cr}(\mathrm{III})$ adsorbs onto silica gel in the form of $\mathrm{Cr}(\mathrm{OH})^{2+}$, which is an inner-sphere complex. Chang et al. ${ }^{[17]}$ found that $\mathrm{Cr}(\mathrm{III})$ adsorbs on the surface of $\gamma-\mathrm{Al}_{2} \mathrm{O}_{3}$ as
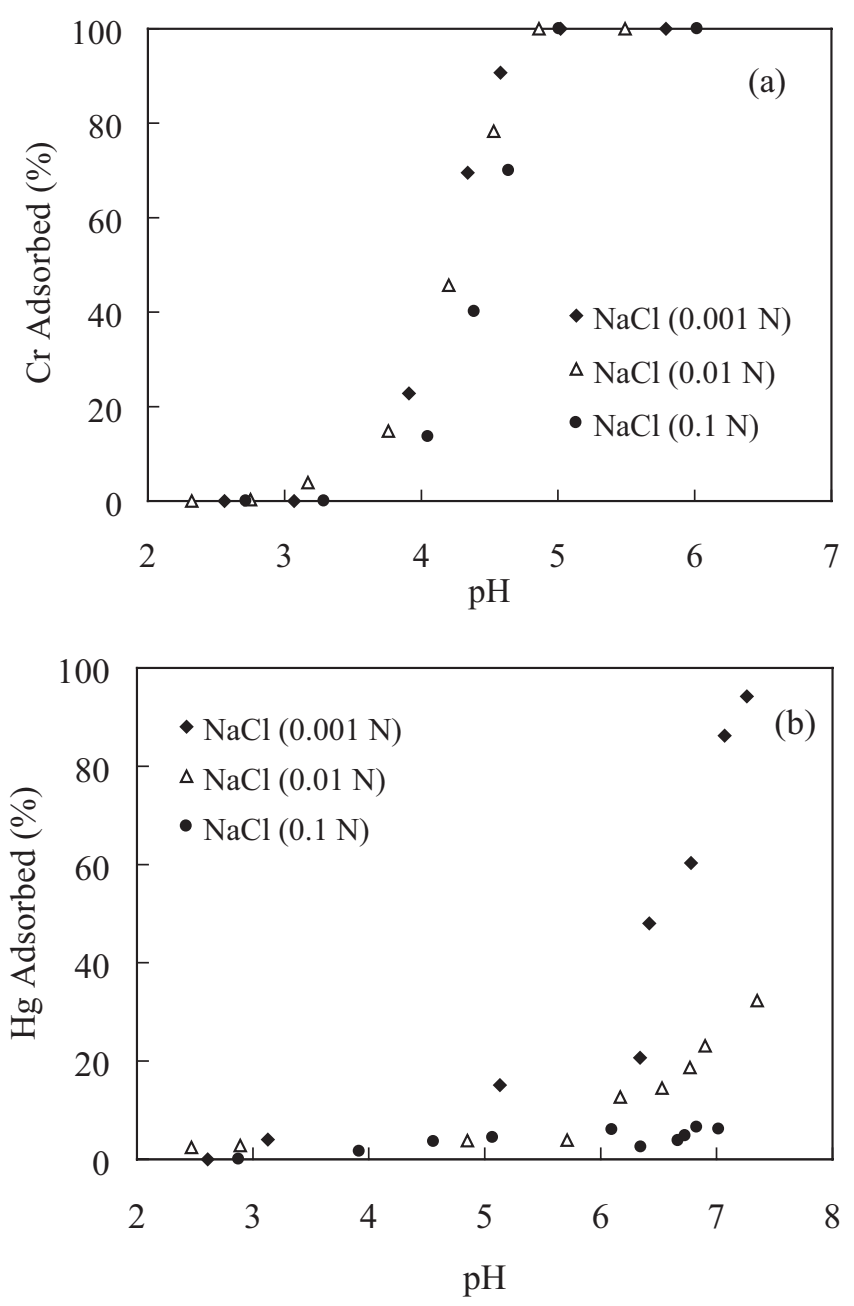

Figure 2. Adsorption of $\mathrm{Cr}(\mathrm{III})$ and $\mathrm{Hg}(\mathrm{II})$ onto sintered material as a function of $\mathrm{pH}$ under various background $\mathrm{NaCl}$ concentrations (a) $[\mathrm{Cr}(\mathrm{III})]_{\mathrm{T}}=40 \mu \mathrm{M}$, adsorbent $=5 \mathrm{~g} / \mathrm{L}$, and $25^{\circ} \mathrm{C}$; (b) $[\mathrm{Hg}(\mathrm{II})]_{\mathrm{T}}=2 \mu \mathrm{M}$, adsorbent $=5 \mathrm{~g} / \mathrm{L}$, and $25^{\circ} \mathrm{C}$. 
co-existent $\mathrm{Cr}^{3+}$ and $\mathrm{Cr}(\mathrm{OH})^{2+} \cdot \mathrm{Cr}^{3+}$ forms an inner-sphere bidentate complex and $\mathrm{Cr}(\mathrm{OH})^{2+}$ forms an inner-sphere monodentate complex on the surface of $\gamma-\mathrm{Al}_{2} \mathrm{O}_{3}$. The sinter includes large amounts of silica and $\mathrm{Al}_{2} \mathrm{O}_{3}$; therefore, its adsorption is similar to that elucidated in previous research, forming inner-sphere complexes on the surface.

The adsorption percentage of $\mathrm{Hg}(\mathrm{II})$ increases with the $\mathrm{pH}$ (Fig. 2b). As shown in Fig. 2b, the background electrolyte clearly influences the adsorption, implying that $\mathrm{Hg}(\mathrm{II})$ may form a $\beta$-plane complex that is similar to an ion pair on the surface of the sinter. Melamed and Villas Boas ${ }^{[18]}$ claimed that the presence of the chloride anion increases the mobility of $\mathrm{Hg}$ (II) through the soil, since mercury chloride has a relatively low affinity at the oxide surface. In the absence of chloride, $\mathrm{Hg}$ (II) forms strong complexes with the surface and its adsorption behavior is consistent with the adsorption of other hydrolyzable cations.

The adsorption density of $\mathrm{Cr}(\mathrm{III})$ and $\mathrm{Hg}(\mathrm{II})$ on the sintered material at equilibrium $\mathrm{pH}=5$ is $1.74 \times 10^{-3}$ and $1.31 \times 10^{-5} \mathrm{mmol} / \mathrm{m}^{2}$. In $\mathrm{Cr}(\mathrm{III}) /$ adsorbent systems, the sintered material $\left(1.74 \times 10^{-3} \mathrm{mmol} / \mathrm{m}^{2}\right)$ shows a greater adsorption density than the water treatment plant sludge $\left(2.62 \times 10^{-4} \mathrm{mmol} / \mathrm{m}^{2}\right)$. In $\mathrm{Hg}$ (II)/ adsorbent systems, the adsorption density of sintered material and the water treatment plant sludge is nearly the same $\left(1.31 \times 10^{-5} \mathrm{mmol} / \mathrm{m}^{2}\right)$. The results indicated that the sintering process does not decline the activity sites of the surface. At equilibrium $\mathrm{pH}=5$, the adsorption density of $\mathrm{Cr}(\mathrm{III})$ on $\gamma-\mathrm{Al}_{2} \mathrm{O}_{3}$, amorphos silica gel, and acid $\mathrm{Al}_{2} \mathrm{O}_{3}$ is $7.50 \times 10^{-4} \mathrm{mmol} / \mathrm{m}^{2}, 2.78 \times 10^{-6} \mathrm{mmol} / \mathrm{m}^{2}$, and $2.51 \times 10^{-5} \mathrm{mmol} / \mathrm{m}^{2}$, respectively. ${ }^{[16,17]}$ The sintered material performs a better efficiency for $\mathrm{Cr}(\mathrm{III})$ removal than other oxides. The variances in the adsorption density for each oxide might be due to differences in laboratory conditions (e.g., adsorbate/adsorbent ratio) and adsorbate affinity for different oxide surface.

The $\mathrm{Cr}(\mathrm{III})$ adsorption isotherm is determined at equilibrium $\mathrm{pH}=4.6 \pm 0.2$. The adsorption capacity of $\mathrm{Cr}(\mathrm{III})$ is simulated by Freundlich and Langmuir isotherms. The simulation shows that the $\mathrm{Cr}(\mathrm{III}) /$ sinter system is saturated and so cannot further adsorb ions. This observation reveals that initially, a high affinity exists between $\mathrm{Cr}$ (III) and the sinter, and the remaining $\mathrm{Cr}$ (III) is not adsorbed onto the surface of the sinter when the adsorption sites are slowly filled. Figure 3a shows that the Freundlich isotherm is not suitable for use in the simulation. $Q_{m}$ (maximum capacity of adsorption $)=1.40(\mathrm{mg} / \mathrm{g})$ and $K$ (Langmuir constant $)=1.62(\mathrm{~L} / \mathrm{mg})$ are determined in the simulation that used the Langmuir isotherm, and the experimental results are consistent with the simulated curve.

The $\mathrm{Hg}(\mathrm{II})$ adsorption isotherm is determined at equilibrium $\mathrm{pH}=6.0 \pm 0.2$. The adsorption capacity of the $\mathrm{Hg}$ (II) is also simulated using Freundlich and Langmuir isotherms (Fig. 3b). Like $\mathrm{Cr}(\mathrm{III})$, the sinter is saturated and cannot adsorb more ions under the experimental conditions. A significant difference exists between the results of the simulation used by the Freundlich isotherm and the corresponding experiment. The simulation conducted using the Langmuir isotherm yields $Q_{m}$ (maximum capacity of adsorption) $=0.43(\mathrm{mg} / \mathrm{g}$ ) and $K$ (Langmuir constant $)=4.3 \times 10^{-4}(\mathrm{~L} / \mathrm{mg})$.

Monser and Adhoum ${ }^{[19]}$ treated wastewater with modified activated carbon and obtained an adsorption capacity of $6.84 \mathrm{mg} \mathrm{Cr} / \mathrm{g}$ adsorbent. Zhang and Bishop ${ }^{[20]}$ used reactivated carbon to adsorb mercury and their result matched that obtained 

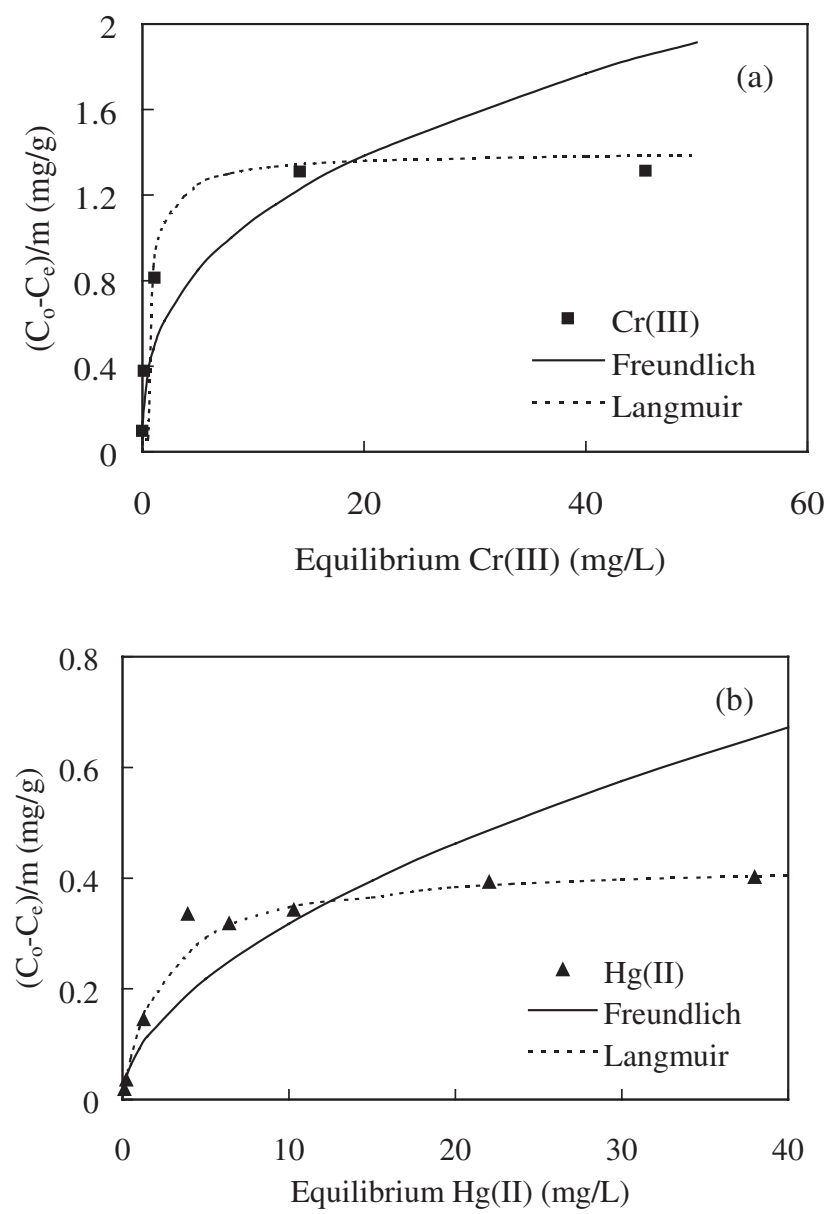

Figure 3. $\mathrm{Cr}(\mathrm{III})$ and $\mathrm{Hg}(\mathrm{II})$ adsorption isotherm by sintered material (a) $\mathrm{Cr}(\mathrm{III})$, adsorbent $=5 \mathrm{~g} / \mathrm{L}$, equilibrium $\mathrm{pH}=4.6 \pm 0.2$, and $25^{\circ} \mathrm{C}$; (b) $\mathrm{Hg}(\mathrm{II})$, adsorbent $=5 \mathrm{~g} / \mathrm{L}$, equilibrium $\mathrm{pH}=6.0 \pm 0.2$, and $25^{\circ} \mathrm{C}$.

with the Freundlich isotherm. The aforementioned studies show that the adsorption capacity and adsorption isotherms are different for different adsorbents. The capacity of the sinter to adsorb $\mathrm{Cr}$, as determined in this study is not as high as that of the modified activated carbon. Its capacity to adsorb $\mathrm{Hg}$ is not as high as that of used tire rubber. ${ }^{[21]}$ However, with reference to recycling, the adsorbent considered in this research can remove $\mathrm{Cr}$ and $\mathrm{Hg}$ without dissolving environmentally harmful heavy metals.

\section{Competitive Adsorption of $\mathrm{Cr}$ (III) and $\mathrm{Hg}$ (II)}

The mobility of cations in the environment is typically regulated by adsorption at the solid/water interface and by competition among various cation species for 
surface binding sites. The strength of these competitive interactions must be determined to predict the water treatment efficiency. Theoretically, multi-component mixture competition involves increasingly complex ion interactions at the water/ oxide interface. Many complex systems exist, and the strength of these competitive interactions must be clarified to better predict the behavior of contaminants. This study seeks to examine the competitive adsorption of $\mathrm{Cr}(\mathrm{III})$ and $\mathrm{Hg}(\mathrm{II})$ at different concentration ratios.

Figures $4 \mathrm{a}-\mathrm{c}$ presents the results of experiments to determine the competitive adsorption of $\mathrm{Cr}(\mathrm{III})$ and $\mathrm{Hg}(\mathrm{II})$ as a function of $\mathrm{pH}$. Notably, when $\mathrm{Cr}(\mathrm{III})$ and
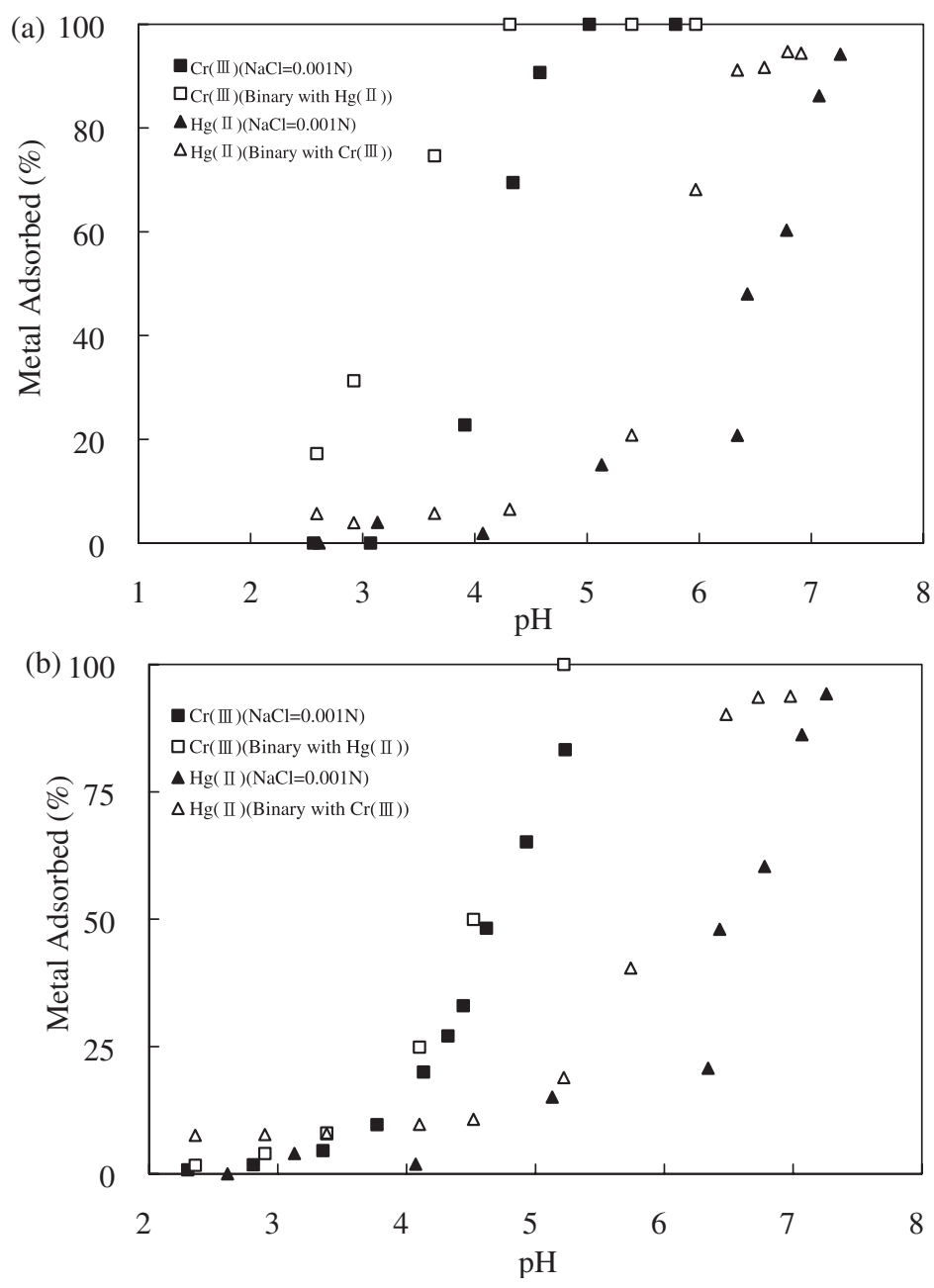

Figure 4. Competitive adsorption envelope of $\mathrm{Cr}(\mathrm{III})$ and $\mathrm{Hg}(\mathrm{II})$ onto sintered material (a) $[\mathrm{Cr}(\mathrm{III})]_{\mathrm{T}}=40 \mu \mathrm{M},[\mathrm{Hg}(\mathrm{II})]_{\mathrm{T}}=2 \mu \mathrm{M}$, adsorbent $=5 \mathrm{~g} / \mathrm{L}$, and $25^{\circ} \mathrm{C}$; (b) $[\mathrm{Cr}(\mathrm{III})]_{\mathrm{T}}=100 \mu \mathrm{M}$, $[\mathrm{Hg}(\mathrm{II})]_{\mathrm{T}}=2 \mu \mathrm{M}$, adsorbent $=5 \mathrm{~g} / \mathrm{L}$, and $25^{\circ} \mathrm{C}$; (c) $[\mathrm{Cr}(\mathrm{III})]_{\mathrm{T}}=400 \mu \mathrm{M},[\mathrm{Hg}(\mathrm{II})]_{\mathrm{T}}=2 \mu \mathrm{M}$, adsorbent $=5 \mathrm{~g} / \mathrm{L}$, and $25^{\circ} \mathrm{C}$.

(continued) 


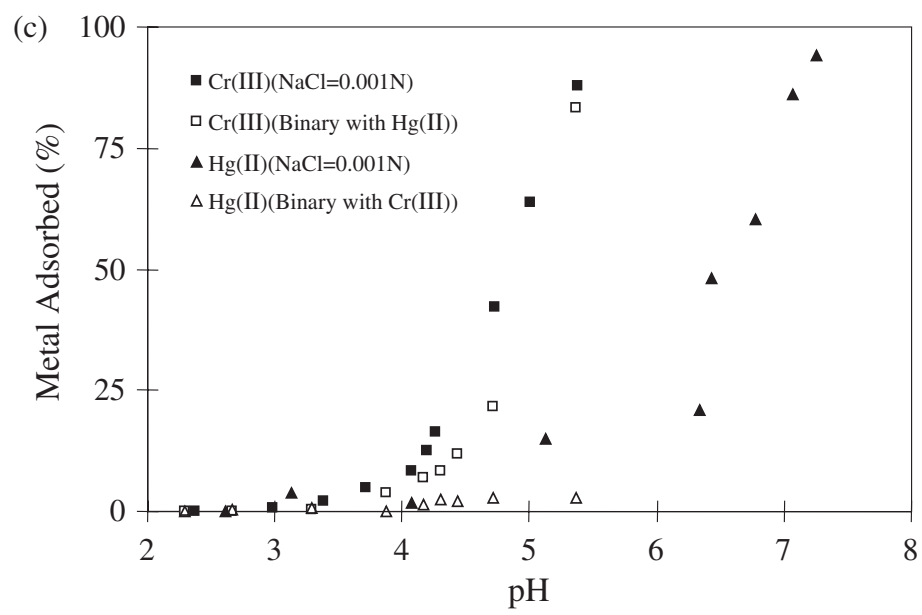

Figure 4. Continued.

$\mathrm{Hg}(\mathrm{II})$ were added alone, more $\mathrm{Cr}(\mathrm{III})$ than $\mathrm{Hg}(\mathrm{II})$ was adsorbed in the range of pH 2-8. When $\mathrm{Cr}$ (III) and $\mathrm{Hg}$ (II) ions were added to form a mixture, more $\mathrm{Cr}$ (III) than $\mathrm{Hg}(\mathrm{II})$ was adsorbed on the surface of sintered material over the range of $\mathrm{pH}$ values studied, but the percentage of $\mathrm{Cr}(\mathrm{III})$ and $\mathrm{Hg}(\mathrm{II})$ adsorbed in the binary system exceeded that in the single-adsorbate system (Fig. 4a), perhaps because the sites on the sintered material surface have a stronger affinity for $\mathrm{Cr}$ (III) than for $\mathrm{Hg}(\mathrm{II})$. The competition between two cations for a given surface site depends on the strength and type of binding between the cation and the surface. $\mathrm{Hg}$ (II) does not affect the adsorption of $\mathrm{Cr}(\mathrm{III})$, implying that the binding of $\mathrm{Cr}$ (III) (inner sphere complex) was stronger than that of $\mathrm{Hg}$ (II) (outer-sphere complex). The other reason for such results may) be that the maximum capacity of adsorption $\left(Q_{m}\right)$ of $\mathrm{Cr}$ (III) $(1.40 \mathrm{mg} / \mathrm{g})$ exceeds that of $\mathrm{Hg}$ (II) $(0.43 \mathrm{mg} / \mathrm{g})$. However, the adsorption of $\mathrm{Cr}$ (III) and $\mathrm{Hg}(\mathrm{II})$ increased considerably in the binary-system, perhaps because the concentration of the competitive adsorbate is far lower than the concentration of the background electrolyte $(0.001 \mathrm{~N})$. Accordingly, the competition for adsorption sites is insignificant at low adsorbate concentration. Figures $4 \mathrm{a}-\mathrm{c}$ also indicate that a higher competitive solute concentration results in a more significant competitive effect on $\mathrm{Hg}(\mathrm{II})$, implying that increasing the competitive adsorbate concentration enhances the opportunity for the competitive adsorbate to occupy the binding sites on the surface of the adsorbent. Hence, the adsorbent surface tended to be more positively charged than the original surface and resisted the adsorption of $\mathrm{Hg}$ (II) onto the sintered material.

\section{CONCLUSION}

The water treatment plant sludge left after water clarification contains various metal oxides. Recycling it by sintering can effectively prevent the release of harmful 
substances in the water treatment plant sludge to the environment. Sintering and reuse not only solves the problem of water treatment plant sludge disposal but also reduces the consumption of natural resources. The adsorption capacity of the sintered material for $\mathrm{Cr}(\mathrm{III})$ is $1.40 \mathrm{mg} / \mathrm{g}$ at equilibrium $\mathrm{pH}=4.6 \pm 0.2$, and $0.43 \mathrm{mg} / \mathrm{g}$ for $\mathrm{Hg}(\mathrm{II})$ at equilibrium $\mathrm{pH}=6.0 \pm 0.2$. $\mathrm{Cr}(\mathrm{III})$ forms an o-plane complex and is not influenced by the background electrolyte, while $\mathrm{Hg}$ (II) forms a $\beta$-plane complex and is affected by the background electrolyte. The $\mathrm{pH}$ ranges for $\mathrm{Cr}$ (III) and $\mathrm{Hg}$ (II) adsorption are $3 \sim 5$ and $5 \sim 7$, respectively. The adsorption of both $\mathrm{Cr}(\mathrm{III})$ and $\mathrm{Hg}(\mathrm{II})$ increases with the $\mathrm{pH}$. Competitive adsorption experiments were conducted to determine the magnitude of concentration variations in adsorption due to competitive interactions between $\mathrm{Cr}(\mathrm{III})$ and $\mathrm{Hg}(\mathrm{II})$, introduced to a system in binary mixtures. The results indicate that a higher competitive solute concentration addition results in a more significant competitive effect on $\mathrm{Hg}$ (II). These observations provide valuable information concerning the treatment of wastewater using an unconventional adsorbent, water treatment plant sludge sinter, as a cost-effective substitute for the classical hydrous-oxide adsorbents, such as silica, alumina, and ferric oxides.

\section{ACKNOWLEDGMENTS}

The authors would like to thank the National Science Council of the Republic of China for financially supporting this research under Contract No. NSC 90-2211-E002-038.

\section{REFERENCES}

1. Sengupta, A.K.; Bo, S. Selective alum recovery from clarifier sludge. Journal of the American Water Works Association 1992, 84, 96-103.

2. Petruzzelli, D.; Volpe, A.; Limoni, N.; Passino, R. Coagulants removal and recovery from water clarifier sludge. Water Research 2000, 34, 2177-2182.

3. Kuai, L.; Doulami, F.; Verstraete, W. Sludge treatment and reuse as soil conditioner for small rural communities. Bioresource Technology 2000, 73, 213-219.

4. Dirk, G. Pulverised fuel ash products solve the sewage sludge problems of the wastewater industry. Waste Management 1996, 16, 51-57.

5. Kayaalp, N.M. Regulatory framework in South Australia and reclaimed water reuse options and possibilities. Desalination 1996, 106, 317-322.

6. Liaw, C.T.; Chang, H.L.; Hsu, W.C.; Huang, C.R. A novel method to reuse paper sludge and co-generation ashes from paper mill. Journal of Hazardous Materials 1998, 58, 93-102.

7. Basegio, T.; Berutti, F.; Bernardes, A.; Bergmann, C.P. Environmental and technical aspects of the utilization of tannery sludge as a raw material for clay products. Journal of European Ceramic Society 2002, 22, 2251-2259. 
8. Anderson, M.; Skerratt, R.G.; Thomas, J.P.; Clay, S.D. Case study involving using fluidized bed incinerator sludge ash as a partial clay substitute in brick manufacture. Water Science and Technology 1996, 34, 507-515.

9. Okuno, N.; Takahashi, S. Full scale application of manufacturing bricks from sewage. Water Science and Technology 1997, 36, 243-250.

10. Tay, J.H.; Show, K.Y. Resource recovery of sludge as a building and construction material - a future trend in sludge management. Water Science and Technology 1997, 36, 259-266.

11. Wiebusch, B.; Seyfried, C.F. Utilization of sewage sludge ashes in the brick and tile industry. Water Science and Technology 1997, 36, 251-258.

12. Wiebusch, B.; Ozaki, M.; Watanabe, H.; Seyfried, C.F. Assessment of leaching tests on construction material made of incinerator ash (sewage sludge): investigations in Japan and Germany. Water Science and Technology 1998, 38, 195-205.

13. Karius, V.; Hamer, K. pH and grain-size variation in leaching tests with bricks made of harbour sediments compared to commercial bricks. The Science of the total Environment 2001, 278, 73-85.

14. Chu, W. Lead metal removal by recycled alum sludge. Water Research 1999, 33, 3019-3025.

15. Nowok, J.W.; Benson, S.A.; Jones, M.L.; Kalmanovitch, D.P. Sintering behavior and strength development in various coal ashes. Fuel 1990, 69, $1020-1028$.

16. Csoban, K.; Joo, P. Sorption of $\mathrm{Cr}(\mathrm{III})$ on silica and aluminium oxide: experiments and modeling. Colloids and Surfaces A: Physicochemical and Engineering Aspects 1999, 151, 97-112.

17. Chang, K.S.; Lin, C.F.; Lee, D.Y.; Lo, S.L.; Yasunaga, T. Kinetic of Cr(III) adsorption/desorption at the $\gamma-\mathrm{Al}_{2} \mathrm{O}_{3} /$ water interface by the pressure-jump technique. Journal of Colloid and Interface Science 1994, 165, 169-176.

18. Melamed, R.; Villas Boas, R.C. Phosphate-background electrolyte interaction affecting the transport of mercury through a Brazilian oxisol. The Science of the total Environment 1998, 213, 151-156.

19. Monser, L.; Adhoum, N. Modified activated carbon for the removal of copper, zinc, chromium, and cyanide from wastewater. Separation and Clarification Technology 2002, 26, 137-146.

20. Zhang, J.; Bishop, P.L. Stabilization/solidification (S/S) of mercury-containing wastes using reactivated carbon and Portland cement. Journal of Hazardous Materials 2002, 92, 199-212.

21. Meng, X.; Hua, Z.; Dermatas, D.; Wang, W.; Kuo, H.Y. Immobilization of mercury(II) in contaminated soil with used tire rubber. Journal of Hazardous Materials 1998, 57, 231-241.

Received September 2, 2003 


\section{Request Permission or Order Reprints Instantly!}

Interested in copying and sharing this article? In most cases, U.S. Copyright Law requires that you get permission from the article's rightsholder before using copyrighted content.

All information and materials found in this article, including but not limited to text, trademarks, patents, logos, graphics and images (the "Materials"), are the copyrighted works and other forms of intellectual property of Marcel Dekker, Inc., or its licensors. All rights not expressly granted are reserved.

Get permission to lawfully reproduce and distribute the Materials or order reprints quickly and painlessly. Simply click on the "Request Permission/ Order Reprints" link below and follow the instructions. Visit the U.S. Copyright Office for information on Fair Use limitations of U.S. copyright law. Please refer to The Association of American Publishers' (AAP) website for guidelines on Fair Use in the Classroom.

The Materials are for your personal use only and cannot be reformatted, reposted, resold or distributed by electronic means or otherwise without permission from Marcel Dekker, Inc. Marcel Dekker, Inc. grants you the limited right to display the Materials only on your personal computer or personal wireless device, and to copy and download single copies of such Materials provided that any copyright, trademark or other notice appearing on such Materials is also retained by, displayed, copied or downloaded as part of the Materials and is not removed or obscured, and provided you do not edit, modify, alter or enhance the Materials. Please refer to our Website User Agreement for more details.

\section{Request Permission/Order Reprints}

Reprints of this article can also be ordered at http://www.dekker.com/servlet/product/DOI/101081ESE120027737 